\title{
OPINIS KOLITAS: RIZIKOS VEIKSNIAI, DIAGNOSTIKA, GYDYMAS
}

\author{
Aistė Naujokaitytė \\ Vilniaus universiteto Medicinos fakultetas
}

Raktažodžiai: opinis kolitas, rizikos veiksniai, opinio kolito diagnostika ir gydymas.

\section{Santrauka}

Opinis kolitas - tai lètinis storosios žarnos uždegimas, kuris prasideda dèl genetiškai nulemto sutrikusio imuninio žarnų gleivinès atsako ị žarnų bakterinès floros antigenus. Sergant opiniu kolitu, paviršiniai uždegiminiai pokyčiai, apimantys gleivinę ir pogleivị, prasideda nuo tiesiosios žarnos ir plinta proksimaliai, pažeisdami visą storosios žarnos gleivinę. Dažniausiai opinis kolitas pasireiškia viduriavimu su krauju ir diagnozuojamas atliekant kolonoskopiją bei histologinius storžarnès tyrimus. Opinio kolito gydymo tikslas - sukelti ir palaikyti ligos remisiją. Tyrimo tikslas - ivvertinti, susisteminti ir išanalizuoti mokslinėje literatūroje pateikiamus duomenis apie opinị kolitą, reikšmingus rizikos veiksnius, galinčius turèti ịtakos šios patologijos vystymuisi, diagnostikos bei gydymo taktikos ypatumus.

\section{Ivadas}

Opinis kolitas - tai lètinis storosios žarnos uždegimas, kuris prasideda dèl genetiškai nulemto sutrikusio imuninio žarnų gleivinès atsako ị žarnų bakterinès floros antigenus. Sergant opiniu kolitu, paviršiniai uždegiminiai pokyčiai, apimantys tik gleivinę ir pogleivi, prasideda nuo tiesiosios žarnos ir plinta proksimaliai, pažeisdami visą storosios žarnos gleivinę. Ši liga kyla dẻl sutrikusios žarnų gleivinès imuninio atsako į žarnų turinyje esančius antigenus genetiškai ị tai linkusiam asmeniui. Tai dažniausia uždegiminės žarnų ligos forma pasaulyje, dažniausiai pasireiškianti 30-40 m. amžiaus asmenims [1]. Šios ligos patogenezè yra daugiaveiksnè, apimanti asmens genetini polinkị, epitelio barjero defektus, pakitusị imuninị atsaką bei aplinkos veiksnius [2]. Dažniausiai opinis kolitas pasireiškia viduriavimu su krauju ir diagnozuojamas atliekant kolonoskopiją bei histologinius storžarnès tyrimus. Opinio kolito gydymo tikslas - sukelti ir palaikyti ligos remisiją. Aminosalicilatai yra pagrindinis lengvos arba vidutinès eigos opinio kolito gydymo pasirinkimas, vietiniai ir sisteminiai steroidai gali būti naudojami paūmèjimams gydyti, o imunosupresantai ir biologiniai vaistai - esant vidutinio sunkumo ir sunkiai ligai. Kolektomija reikalinga iki 15 proc. pacientų, sergančiu opiniu kolitu [1].

Tyrimo tikslas - išanalizuoti bei aptarti įrodymais pagrịstą informaciją apie opinio kolito rizikos veiksnius, diagnostiką bei gydymą.

\section{Tyrimo medžiaga ir metodai}

Taikyta sisteminè mokslinès literatūros bei dokumentu apžvalga ir analizė. Duomenų buvo ieškoma Google Scholar, UpToDate, Cochrane bei Medline (PubMed) duomenu bazèse. Visateksčiai straipsniai atrinkti, jei jų pavadinimas, santrauka ar reikšminiai žodžiai nurodè, kad tyrimas tinkamas įtraukti į šią apžvalgą. Pasirinktos tik anglų kalba skelbtos publikacijos. Vartoti nurodyti raktažodžiai. Atrinkti, išanalizuoti ir apibendrinti 6 straipsniai.

\section{Tyrimo rezultatai}

Rizikos veiksniai. 8-14 proc. pacientų, sergančių opiniu kolitu, turi giminių, sirgusių uždegimine žarnyno liga, o pirmos eilès giminių net keturis kartus didesné tikimybė susirgti. Žydų populiacijoje opinio kolito dažnis didesnis, negu kitų tautybių atstovų [1]. Uždegiminèmis žarnyno ligomis rečiau serga juodaodžiai ir ispanų bendruomenès, palyginti su baltaodžių populiacija. İtakos susirgti opiniu kolitu turi gyvenimo būdas. Rūkymas yra rizikos veiksnys susirgti Krono liga, tačiau ne opiniu kolitu, anot atliktų tyrimų, rūkymas gali sumažinti riziką susirgti opiniu kolitu [3]. Yra žinoma, kad anksčiau rūkiusių asmenų didesnè rizika susirgti opiniu kolitu, kai tuo tarpu rūkančių asmenų, palyginti su metusiais rūkyti ir nerūkančiais, rizika susirgti mažesnè, o susirgus būdinga lengvesné ligos eiga [1]. Paciento mityba taip pat gali turèti ịtakos opinio kolito atsiradimui. Didesnis riebalu vartojimas, tiek gyvulinių riebalų, tiek polinesočiujų riebalų rūgščiu yra siejamas su didesne rizika susirgti uždegimine žarnyno liga [3].

Manoma, kad apendektomija veikia kaip apsaugantis nuo opinio kolito vystymosi veiksnys, ypač tai atvejais, kai apendektomija atlikta jauniems pacientams [4]. Vaistų, tokių kaip geriamieji kontraceptikai, nesteroidiniai vaistai nuo už- 
degimo, vartojimas yra siejamas su padidejjusia opinio kolito rizika, tačiau antibiotikams toks poveikis nèra būdingas. Panašu, kad žindymas krūtimi mažina opinio kolito atsiradimo riziką, o gyvenimas mieste šią riziką didina. Apibendrinti 11 Europos perspektyvinių tyrimų duomenys nenustatė ryšio tarp streso ir naujai atsiradusio opinio kolito [5].

Diagnostika. Opinio kolito diagnozė grindžiama lètiniu viduriavimu ilgiau negu keturias savaites, endoskopiškai aptiktu aktyviu žarnyno uždegimu bei biopsioje rastais lètiniais pokyčiais. Kadangi šie požymiai nèra specifiški tik opiniam kolitui, nustatant diagnozę taip pat reikètų atmesti kitas galimas kolito priežastis [6]. Radiologiniai bei laboratoriniai tyrimai nėra lemiami, nustatant opininị kolitą, tačiau gali būti naudingi [1].

Gydymas. Pacientams, sergantiems opiniu kolitu, gydymas pasirenkamas atsižvelgiant ị ligos mastą ir sunkumą. Dažniausiai ligos prognozė per pirmajji dešimtmeti po diagnozès yra gera ir dauguma pacientų patiria remisiją. Kai sergant opiniu kolitu pasireiškia proktitas, medikamentai (žvakutès arba klizmos) skiriami naudoti per tiesiają žarną ir dažniausiai kartu skiriama sisteminè vaistų terapija. Pirmo pasirinkimo vaistai yra sulfasalazinas ir 5-aminosalicilatai, vartojami per os arba per rectum. Pacientams, kurie per dvi savaites nepasiekia remisijos, galima paskirti gliukokortikoidų. Visi išvardinti vaistai, išskyrus gliukokortikoidus, gali būti naudojami remisijos palaikymui. Taip pat yra ịrodymų, kad probiotikai naudingi, siekiant remisijos. Jeigu organizmas atsparus gliukokortikoidams, galima paskirti tiopurinus arba biologinius vaistus [2].

\section{Išvados}

1. Genetinè predispozicija, teigiama šeiminè anamnezė bei aplinkos veiksniai turi įtakos opinio kolito išsivystymui.

2. Opinio kolito simptomų pasireiškimas bei būdingi endoskopiniai ir histologiniai radiniai dažnai tampa svarbiausiu diagnostiniu kriterijumi. Radiologiniai ir laboratoriniai tyrimai gali padèti patvirtinti diagnozę.

3. Pirmo pasirinkimo vaistai yra sulfasalazinas ir 5-aminosalicilatai. Nesant gydymo efekto, vaistai turi būti koreguojami.

\section{Literatūra}

1. Ungaro R, Mehandru S, Allen PB, Peyrin-Biroulet L, Colombel J-F. Ulcerative colitis. Lancet 2017;389(10080):1756-70. https://doi.org/10.1016/S0140-6736(16)32126-2

2. Lynch WD, Hsu R. Ulcerative colitis. Treasure Island (FL): StatPearls Publishing 2021. http://www.ncbi.nlm.nih.gov/ books/NBK459282/

3. Peppercorn MA, Cheifetz AS. Definitions, epidemiology, and risk factors for inflammatory bowel disease in adults.
UpToDate 2021. https://www.uptodate.com/contents/ definitions-epidemiology-and-risk-factors-for-inflammatory-bowel-disease-in-adults? search $=$ ulcerative $\% 20$ colitis\&topicRef $=4067 \&$ source $=$ see_link\#H3681058044

4. Sahami S, Kooij IA, Meijer SL, Van den Brink GR, Buskens CJ, Te Velde AA. The link between the appendix and ulcerative colitis: clinical relevance and potential immunological mechanisms. Am J Gastroenterol 2016;111(2):163-9.

https://doi.org/10.1038/ajg.2015.301

5. Heikkilä K, Madsen IEH, Nyberg ST, Fransson EI, Ahola K, Alfredsson L, et al. Job strain and the risk of inflammatory bowel diseases: individual-participant meta-analysis of 95,000 men and women. PLoS One 2014;9(2):e88711.

https://doi.org/10.1371/journal.pone.0088711

6. Peppercorn MA, Kane SV. Clinical manifestations, diagnosis, and prognosis of ulcerative colitis in adults. UpToDate 2021. https://www.uptodate.com/contents/clinical-manifestationsdiagnosis-and-prognosis-of-ulcerative-colitis-in adults? search $=$ ulcerative $\% 20$ colitis $\&$ source $=$ search_res ult\&selectedTitle $=1 \sim 150 \&$ usage_type $=$ default\&display rank=1\#H25426526

\section{ULCERATIVE COLITIS - RISK FACTORS, DIAGNOSIS AND TREATMENT A. Naujokaitytè}

Keywords: ulcerative colitis, risk factors, diagnosis and treatment of ulcerative colitis.

Summary. Ulcerative colitis is a chronic inflammation of the colon that begins as a result of a genetically impaired response of the intestinal mucosa to antigens from the gut bacterial flora.In ulcerative colitis, inflammatory changes begin in the rectum and spread proximally, damaging the entire mucosa of the large intestine, they are superficial, involving only the mucosa and submucosa. Ulcerative colitis usually presents with diarrhea with blood and is diagnosed by colonoscopy and histological examination of the colon. The goal of treatment for ulcerative colitis is to induce and maintain remission of the disease. The aim of this study was to evaluate, systematize and analyze the data presented in the scientific literature on ulcerative colitis, what significant risk factors may influence the development of this pathology, what diagnosis and treatment tactics are best chosen for this disease.

Conclusions. 1. Genetic predisposition, positive family history and environmental factors influence the development of ulcerative colitis. 2. The onset of ulcerative colitis symptoms and characteristic endoscopic and histological findings often become the most important diagnostic criterion. Radiological and laboratory tests can help confirm the diagnosis. 3 . The drugs of first choice are sulfasalazine and 5-aminosalicylates, and in the absence of a therapeutic effect, the drugs must be adjusted.

Correspondence to: aiste.naujokaityte@mf.stud.vu.lt

Gauta 2021-04-18 